\title{
Astrovirus infection in children living in the Central West region of Brazil
}

\section{Rodrigo Alessandro Tôgo Santos, Ana Maria Tavares Borges, Paulo Sérgio Sucasas da Costa*, José Marcus Sócrates Teixeira ${ }^{* *}$, Loreny Gimenes Giugliano ${ }^{* * *}$, José Paulo Gagliardi Leite ${ }^{* * * *}$, Divina das Dôres de Paula Cardoso/ ${ }^{+}$}

\begin{abstract}
Laboratório de Virologia, Instituto de Patologia Tropical e Saúde Pública *Departamento de Pediatria e Puericultura, Faculdade de Medicina, Universidade Federal de Goiás, Rua 235 esquina com a 1a avenida s/nōo, Setor Universitário, 74605-050 Goiânia, GO, Brasil

** Instituto de Saúde do Distrito Federal, Brasília, DF, Brasil ${ }^{* * *}$ Laboratório de Microbiologia, Instituto de Ciências Biológicas, Universidade de Brasília, Brasília, DF, Brasil ${ }^{* * * *}$ Laboratório de Virologia Comparada, Departamento de Virologia, Instituto Oswaldo Cruz-Fiocruz, Rio de Janeiro, RJ, Brasil
\end{abstract}

This study presents data regarding the circulation of astrovirus in Goiânia-GO and Brasília-DF. These viruses were detected in fecal samples from hospitalized children up to five years old with and without acute gastroenteritis. A total of 1244 fecal samples were collected in two periods, 1994 to 1996 (Brasília) and 1998 to 2002 (Goiannia and Brasília), and were analyzed for viral RNA using the reverse transcription-polymerase chain reaction (RT-PCR). Positivity rates of 4.3 and $0.5 \%$ for astrovirus were observed in children with acute gastroenteritis and those without gastroenteritis, respectively. Among children with gastroenteritis no statistically significant difference was seen with regards to viral positivity rates in relation to gender and age. However, a higher incidence rate was observed for children from Brasília aged 36 months or more. Overall, astroviruses occurred predominantly from September to March in the two cities, suggesting a seasonal pattern for these viruses which coincides with the highest relative air humidity period. The results of this study highlight the importance of astrovirus as an etiologic agent of acute gastroenteritis in children of the Central West region of Brazil.

Key words: astrovirus - gastroenteritis - epidemiology - reverse transcription-polymerase chain reaction - Goiás - Brasília - Brazil

Acute gastroenteritis (AG) is considered a significant cause of morbidity and mortality in humans worldwide (Glass et al. 2001). The mortality rate has been estimated in more than three million of persons per year with the majority of deaths occurring in the developing countries (Wilhelmi et al. 2003). Viral enteric pathogens are recognized as important agents related to such a syndrome with major pathogens being Rotavirus $A$, enteric adenovirus, human calicivirus and astrovirus (Wilhelmi et al. 2003).

The astroviruses, family Astroviridae, genus $\mathrm{Ma}$ mastrovirus include eight types that infect humans (ICTVdB Management 2006). They have been associated with outbreaks of diarrhea involving young children and other age groups in different parts of the world (Matsui \& Greenberg 2001). The viruses have a plussense, single-stranded RNA (ssRNA) genome with approximately 6800 nucleotides with polyadenilated tail at the 3-end (Matsui \& Greenberg 2001). The genome presents three open reading frames: ORF1a, ORF1b, and ORF2, each encoding at the least one polyprotein.

Financial support: CNPq (no.520729/99-4 and 471968/2003-0)

+Corresponding author: dcardoso@iptsp.ufg.br

Received 21 November 2006

Accepted 22 February 2007
Different methodologies have been employed for the detection and characterization of these viruses including electron- and- immune electron microscopy, enzyme immunoassay, latex agglutination, viral isolation in cell culture, and molecular procedures such as reverse transcription-polymerase chain reaction (RT-PCR) (Silva et al. 2001, Komoriya et al. 2003, Tai et al. 2003, MéndezToss et al. 2004). The RT-PCR has been widely utilized for both viral detection and genotyping using primers designed for each one of genomic regions (Noel et al. 1995, Belliot et al. 1997).

The astroviruses are recognized as one of the most common cause of viral gastroenteritis in infants and young children in worldwide (Giordano et al. 2001) and its seasonality is variable according to the geographic region (Naficy et al. 2000, Guix et al. 2002). The main symptom of the astrovirus infections is a watery and mild diarrhea, which generally results in mild diarrheic disease (Matsui \& Greenberg 2001), although a recent study has described astrovirus infection related to severe dehydrating gastroenteritis among isolated Brazilian communities (Gabbay et al. 2006).

In Brazil, there are few studies about the occurrence of these viruses which show prevalence rates ranging between 3 and 56\% (Stewien et al. 1991, Tanaka et al. 1994, Silva et al. 2001, Gabbay et al. 2006). Considering the Central West region of the country, only one study was carried out which showed astrovirus detection rate of 2.8\% (Cardoso et al. 2002). This study presents epidemiological and clinical data regarding the circulation of 
astrovirus in two cities of the Central West region of Brazil which were detected in children with and without AG.

\section{MATERIALS AND METHODS}

Subject - The study was performed using 1244 fecal samples collected from hospitalized children at public hospitals in the cities of Goiânia, Goiás (1998 to 2002) and Brasília, Distrito Federal (1994 to 1996 and 1998 to 2002), aged up to five years. Of these, 1041 samples were from children with acute diarrhea (AG) which was defined as three or more liquid or semiliquid evacuations per day, and 203 from non-diarrheic children; 743 samples were from children from Goiânia-GO (699 with $\mathrm{AG}$ and 44 without $\mathrm{AG}$ ) and 501 from children living in Brasília-DF (342 with AG and 159 without AG). All samples from Goiânia were collected "in nature" while of the Brasília samples, 204 samples were collected "in nature" and 297 by rectal swab. Considering the last population census carried out by Instituto Brasileiro de Geografia e Estatística (IBGE 2000), the sampling analyzed in relation to the infantile population was regarded as representative in both cities $(95 \%$ confidence interval). All samples were primarily screened for rotavirus and adenovirus utilizing a combined enzyme immunoassay for Rotavirus A and adenovirus - EIARA - (Pereira et al. 1985) and also by polyacrylamide gel electrophoresis - PAGE (Pereira et al. 1983). Samples were also screened for calicivirus by RT-PCR using primers designed for the RNA polymerase region (Green et al. 1995, Vinjé et al. 1997, Jiang et al. 1999).

The collection of fecal samples was carried out after a written informed consent was provided by parents or legal guardians and the study was approved by the Ethics Committee on Research of the Federal University of Goiás (no. 004/2000).

Detection of astrovirus - The astrovirus was detected by RT-PCR using primers designed by Noel et al. (1995). For the procedure, initially, the viral ssRNA was extracted from $300 \mu \mathrm{l}$ fecal suspension (20\% in phosphate buffered saline - PBS - pH 7.4) following methodology described by Boom et al. (1990) with modifications (Cardoso et al. 2002). The reverse transcription was carried out using $16 \mu \mathrm{l}$ of viral ssRNA added of $2 \mu \mathrm{l}$ random primer $\operatorname{pd}(\mathrm{N})_{6}$ (Random Hexamer, Amersham Biosciences) at temperature of $42^{\circ} \mathrm{C}$ for 60 min with a reaction mixture in a final volume of $50 \mu 1$ [1X reaction buffer - PCR buffer - (TRIS-HCl $20 \mathrm{mM} \mathrm{pH} \mathrm{8.4,50}$ $\mathrm{mM} \mathrm{KCl}$ ); $0.4 \mathrm{mM}$ of each dNTP; $4.0 \mathrm{mM}$ of $\mathrm{MgCl}_{2} ; 20$ $\mathrm{U} / \mathrm{ml}$ of ribonuclease inhibitor (Invitrogen ${ }^{\mathrm{TM}} / \mathrm{Life}$ Technologies); $120 \mathrm{U} / \mathrm{ml}$ of the MMLV reverse transcriptase enzyme (Gibco BRL ${ }^{\circledR} /$ Life Technologies)]. The PCR was carried out using $10 \mu \mathrm{l}$ of the cDNA and the specific primers Mon 269-270 (0.4 $\mu \mathrm{M}$ of each primer) (Noel et al. 1995) in a reaction mixture also in a final volume of $50 \mu \mathrm{l}$. The reaction mixture contained the same reagents, at same concentrations, except the not utilization of the ribonuclease inhibitor and reverse transcriptase, and the use of $2.5 \mathrm{U} / \mu \mathrm{l}$ of the Taq DNA polymerase enzyme (Invitrogen ${ }^{\mathrm{T}} / \mathrm{Life}$ Technologies) as well as 1.2 $\mathrm{mM}$ of $\mathrm{MgCl}_{2}$. The amplification was carried out in 40 cycles $\left(94^{\circ} \mathrm{C}-30 \mathrm{~s}, 50^{\circ} \mathrm{C}-30 \mathrm{~s}\right.$, and $\left.72^{\circ} \mathrm{C}-60 \mathrm{~s}\right)$, following of a final extension at $72^{\circ} \mathrm{C}$ for $10 \mathrm{~min}$ (Eppendorf Mastercycler Personal). The amplified product (449 bp) was visualized from 1.5\% agarose gel electroforesis with ethidium bromide staining $(0.5 \mathrm{mg} /$ ml) (Macro Vue UV-20 - Hoefer Scientific Instruments) by comparison with the molecular pattern - $123 \mathrm{bp}$ DNA ladder (Invitrogen ${ }^{\mathrm{TM}} / \mathrm{Life}$ Technologies). In all reactions positive samples were included, provided by Laboratório de Virologia Comparada-Fiocruz, Rio de Janeiro, Brazil, as positive control, and sterile Milli-Q water as negative control. All the stages of the reaction were done in separated places aiming to avoid contaminations.

Statistical analysis - The statistical analysis was done using the program Epiinfo version 6.04d. Chi-square test $\left(\chi^{2}\right)$ with $95 \%$ confidence interval and the Fisher exact test, when necessary, were calculated.

\section{RESULTS}

From 1244 fecal specimens, 46 (3.7\%) were positive for astrovirus. The highest viral detection rate was observed in children with AG from Brasília city (7\%). Only one child without AG was positive for astrovirus (Table I).

There was no statistically significant difference of positivity rates in relation to gender for children with AG (27/596-4.5\%-male; $18 / 445-4 \%$-female) $\left(\chi^{2}=0.05\right.$ $\mathrm{p}=0.8205)$. Similarly, although a higher positivity rate was observed in children more than 36 months old (7.3\%), no statistically significant difference could be noted with respect to the age groups (Table II).

Astroviruses occurred year-round in all years, predominantly from September to March in both cities (Table III).

Diarrhea was observed in all children and analysis of astrovirus positivity in relation to other gastroenteritis symptoms such as vomiting, fever and abdominal pain in association with the diarrhea was performed for children from Goiânia where it was not observed statistically significant difference (Table IV).

Of 46 astrovirus-positive samples, 14 (30.4\%) were also positive for other viruses, as follows: seven samples were also positive for Rotavirus A, six for calicivirus and another for specie A adenovirus.

TABLE I

Distribution of astrovirus in fecal samples from children with or without acute gastroenteritis (AG) in relation to city of collection

\begin{tabular}{|c|c|c|c|c|c|c|}
\hline \multirow[b]{2}{*}{ City } & \multicolumn{2}{|c|}{ With AG } & \multicolumn{2}{|c|}{ Without AG } & \multicolumn{2}{|c|}{ Total } \\
\hline & No. & $\%$ & No. & $\%$ & No. & $\%$ \\
\hline Goiânia-GO & $21 / 699$ & 3.0 & $0 / 44$ & 0.0 & $21 / 743$ & 2.8 \\
\hline Brasília-DF & $24 / 342$ & $7.0^{a}$ & $1 / 159$ & 0.6 & $25 / 501$ & $5.0^{b}$ \\
\hline Total & $45 / 1041$ & 4.3 & $1 / 203$ & $0.5^{c}$ & $46 / 1244$ & 3.7 \\
\hline
\end{tabular}

$a: \chi^{2}=8.00, \mathrm{p}=0.0046 ; b: \chi^{2}=3.35, \mathrm{p}=0.0672 ; c: \chi^{2}=5.96, \mathrm{p}=0.0146$. 
TABLE II

Distribution of astrovirus in fecal samples from children with acute gastroenteritis (AG), considering cities of collection, in relation to age group

\begin{tabular}{|c|c|c|c|c|c|c|}
\hline \multirow{2}{*}{$\begin{array}{l}\text { Age group } \\
\text { (months) }\end{array}$} & \multicolumn{2}{|c|}{ Brasília $^{d}$} & \multicolumn{2}{|c|}{ Goiânia } & \multicolumn{2}{|c|}{ Total } \\
\hline & No. & $\%$ & No. & $\%$ & No. & $\%$ \\
\hline $0-6$ & $6 / 100$ & 6.0 & $5 / 153$ & $3.3^{b}$ & $11 / 253$ & 4.3 \\
\hline $7-12$ & 4/92 & 4.3 & $9 / 275$ & 3.3 & $13 / 367$ & 3.5 \\
\hline $13-24$ & $2 / 87$ & 2.3 & $4 / 142$ & 2.8 & $6 / 229$ & 2.6 \\
\hline $25-36$ & $2 / 28$ & 7.1 & $1 / 63$ & 1.6 & $3 / 91$ & 3.3 \\
\hline$>36$ & $5 / 24$ & $20.8^{a}$ & $1 / 58$ & 1.7 & $6 / 82$ & $7.3^{c}$ \\
\hline Total & $19 / 331$ & 5.7 & $20 / 691$ & 2.9 & $39 / 1022$ & 3.8 \\
\hline
\end{tabular}

$a$ : Fisher exact test $\mathrm{p}=0.0076 ; b$ : Fisher exact test $\mathrm{p}=0.7849 ; c$ : Fisher exact test $\mathrm{p}=0.1207 ; d$ : from 19 children was not known the age and from that, 6 were positive for astrovirus. The child without AG with positivity for astrovirus had 7 months of age.

TABLE III

Distribution of astrovirus in fecal samples from children with acute gastroenteritis (AG) in relation to the period of year (1994-1996 and 1998-2001) ${ }^{c}$

\begin{tabular}{|c|c|c|c|c|c|c|}
\hline \multirow[b]{2}{*}{ Climatic season } & \multicolumn{2}{|c|}{ Brasília } & \multicolumn{2}{|c|}{ Goiânia } & \multicolumn{2}{|c|}{ Total } \\
\hline & No. & $\%$ & No. & $\%$ & No. & $\%$ \\
\hline Dry (April/August) & $0 / 58$ & 0.0 & $1 / 296$ & 0.3 & $1 / 354$ & 0.3 \\
\hline Rain (September/March) & $24 / 212$ & 11.3 & $20 / 395$ & $5.1^{a}$ & $44 / 607$ & $7.2^{b}$ \\
\hline Total & $24 / 270$ & 8.9 & $21 / 691$ & 3.0 & $45 / 961$ & 4.7 \\
\hline
\end{tabular}

$a: \chi^{2}=11.27, \mathrm{p}=0.0007 ; b: \chi^{2}=22.78, \mathrm{p}=0.0000 ; c:$ were not included 80 negative samples collected in dry season in the year of 2002 (8 samples from Goiânia and 72 from Brasília); the positive sample from child without AG was collected in dry season.

TABLE IV

Distribution of astrovirus in fecal samples from children from Goiânia, Goiás in relation to the clinical symptoms ${ }^{b}$

\begin{tabular}{llr}
\hline Symptoms & No. & $\%$ \\
\hline Diarrhea, fever, vomiting, and abdominal pain & $6 / 204$ & 2.9 \\
Diarrhea, fever, and vomiting & $5 / 180$ & 2.8 \\
Diarrhea, vomiting, and abdominal pain & $1 / 49$ & 2.0 \\
Diarrhea and vomiting & $7 / 106$ & $6.6^{a}$ \\
Diarrhea & $2 / 61$ & 3.3 \\
\hline Total & $21 / 600$ & 3.5
\end{tabular}

$a$ : Fisher exact test $\mathrm{p}=0.0750 ; b$ : from 99 children have not the disponibility of complete data in relation to the symptoms presented.

\section{DISCUSSION}

Astroviruses are considered important viral enteric pathogens in children with and without AG worldwide (Pennap et al. 2002, Méndez-Toss et al. 2004, Gabbay et al. 2005). In this study, a higher detection rate of astrovirus in cases of AG (4.3\%) was observed, as compared to non-diarrheic patients $(0.5 \%)(\mathrm{p}<0.05)$. This result is comparable to those from other studies where viral detection rates in cases of $\mathrm{AG}$ ranged from 1.5 to 20\% (Mitchell et al. 1999, Giordano et al. 2001, Denno et al. 2005). In contrast, results from children without gastroenteritis are lower than those observed in other studies where detection rates of 1.2 to $5.7 \%$ were yielded considering the same population (Pennap et al. 2002, Riechmann et al. 2004).

No significant differences in astrovirus-positivity rate, among children with AG, could be noted in relation to the gender of the children. To our knowledge, a similar analysis was performed only in another study conducted in Rio de Janeiro city, which showed similar results (Miranda 2004, pers. commun.). In children from Goiânia city, it was observed that astrovirus infections occurred in all age groups, with a higher detection rate in children up to 24 months of age. These results reinforce a previous study conducted in the same area (Cardoso et al. 2002) and are also in accordance with a study carried out by Guix et al. (2002) in Spain. In contrast, a higher positivity rate was observed in children older than 36 months of age in Brasília city. This result shows a different pattern if compared to other studies conducted elsewhere (Silva et al. 2001, Giordano et al. 2004). This result should, however, be analyzed with caution owing to the small number of samples from that age group. Further studies are thus needed to confirm this result.

One objective of this study consisted in the analysis of astrovirus positivity in fecal samples from children with diarrhea alone or in association to other clinical manifestations such as vomiting, fever, and abdominal pain. In the present study the astrovirus positivity was not significantly more related to one or more symptoms other than diarrhea considering the children from Goiânia city. These results agree with those from a study carried 
out by López et al. (2000) which analyzed children up to ten years from Spain.

Studies have shown that astroviruses occur preferentially during the colder months of the year (Phan et al. 2004, Galdiero et al. 2005) even though other investigations have shown a higher viral incidence during warmest months (Guerrero et al. 1998, Naficy et al. 2000). Other studies report a year-round occurrence of astroviurs infection (Schnagl et al. 2002, Giordano et al. 2004). In this study, the infection by astrovirus occurred mainly from September to March, considered the rainy season in the region. In accordance with data from the Instituto Nacional de Meteorologia (INMET) - $10^{\underline{o}}$ Distrito de Meteorologia de Goiás e Tocantins, during the years of the study in Goiânia, there was no significant temperature variation throughout the study period, in contrast to the relative air humidity and rainfall indexes, which showed higher and lower indexes between September and March and April and August, respectively. Therefore, the seasonality of astrovirus infection in our study could be associated with the increase of the relative air humidity resulting from heavier rainfalls in the region. These results agree with those from a previous study (Cardoso et al. 2002) and differ from the pattern of rotavirus occurrence in Goiânia city, which is more prominent during the dry months (April to August) (Cardoso et al. 2003, Costa et al. 2004).

Co-infection of astrovirus with other viruses has also been observed in studies carried out by Román et al. (2003) and Phan et al. (2004) in Spain and Pakistan, respectively. In this study, although the association of astrovirus with AG has been demonstrated, a larger proportion $(30.4 \%)$ of samples was also positive for other viruses making it difficult to determine the primary viral pathogen.

Anyway, this study highlights that astrovirus is an important agent of acute gastroenteritis in children from the Central West region of Brazil and provides local preliminary epidemiologic features of the disease. Our findings may also be of importance with respect to the implementation of prevention and control measures.

\section{ACKNOWLEDGEMENTS}

To Dr João Bosco Siqueira Júnior for technical assistance in this manuscript.

\section{REFERENCES}

Belliot G, Laveran H, Monroe SS 1997. Detection and genetic differentiation of human astroviruses: phylogenetic grouping varies by coding region. Arch Virol 142: 1323-1334.

Boom R, Sol CJA, Salimans MMM, Jansen CL, Wertheim-Van Dillen PME, Van Der Noordaa J 1990. Rapid and simple method for purification of nucleic acids. J Clin Microbiol 28: 495-503.

Cardoso DDP, Fiaccadori FS, Souza MBLD, Martins RMB, Leite JPG 2002. Detection and genotyping of astroviruses from children with acute gastroenteritis from Goiânia, Goiás, Brazil. Med Sci Monit 8: CR624-628.

Cardoso DDP, Soares CMA, Souza MBLD, Azevedo MSP, Martins RMB, Queiróz DAO, Brito WMED, Munford V, Rácz ML 2003. Epidemiological features of rotavirus infec- tion in Goiânia, Goiás, Brazil, from 1986 to 2000. Mem Inst Oswaldo Cruz 98: 25-29.

Costa PSS, Grisi SJFE, Cardoso DPP, Fiaccadori FS, Souza MBLD, Santos RAT 2004. Manifestações clínicas e epidemiológicas das infecções por Rotavirus A. Pediatria (São Paulo) 26: 151-158.

Denno DM, Stapp JR, Boster DR, Qin X, Clausen CR, Del Beccaro KH, Swerdlow DL, Braden CR, Tarr PI 2005. Etiology of diarrhea in pediatric outpatient settings. Pediatr Infect Dis J 24: 142-148.

Gabbay YB, Chamone CB, Nakamura LS, Oliveira DS, Abreu SF, Cavalcante-Pepino EL, Mascarenhas JDAP, Leite JPG, Linhares AC 2006. Characterization of an astrovirus genotype 2 strain causing an extensive outbreak of gastroenteritis among Maxakali Indians, Southeast Brazil. J Clin Virol 37: 287-292.

Gabbay YB, Luz CRNE, Costa IV, Cavalcante-Pepino EL, Sousa MS, Oliveira KK, Wanzeller ALM, Mascarenhas JDAP, Leite JPG, Linhares AC 2005. Prevalence and genetic diversity of astroviruses in children with and without diarrhea in São Luís, Maranhão, Brazil. Mem Inst Oswaldo Cruz 100: 709-714.

Galdiero E, Marinelli A, Pisciotta MG, Pagliara I, Di Monteforte ES, Liguori G 2005. Reverse transcriptase-PCR for the detection of astrovirus in children with nosocomial acute diarrhoea in Naples, Italy. Med Mal Infect 35: 213-217.

Giordano MO, Ferreyra LJ, Isa MB, Martinez LC, Yudowsky SI, Nates SV 2001. The epidemiology of acute viral gastroenteritis in hospitalized children in Cordoba City, Argentina: an insight of disease burden. Rev Inst Med Trop São Paulo 43: 193-197.

Giordano MO, Martinez LC, Isa MB, Rearte MP, Nates SV 2004. Childhood astrovirus-associated diarrhea in the ambulatory setting in a public hospital in Cordoba City, Argentina. Rev Inst Med Trop São Paulo 46: 93-96.

Glass RI, Bresee J, Jiang B, Gentsh G, Ando T, Fankhauser R, Noel J, Parashar U, Rosen B, Monroe SS 2001. Gastroenteritis viruses: an overview. Novartis Found Symp 238: 5-19.

Green J, Gallimore CI, Norcott JP, Lewis D, Brown DW 1995. Broadly reactive reverse transcriptase polymerase chain reaction for the diagnosis of SRSV-associated gastroenteritis. J Med Virol 47: 392-398.

Guerrero ML, Noel JS, Mitchell DK, Calva JJ, Morrow AL, Martínez J, Rosales G, Velázquez FR, Monroe SS, Glass RI, Pickering LK, Ruiz-Palacios GM 1998. A prospective study of astrovirus diarrhea of infancy in Mexico City. Pediatr Infect Dis J 17: 723-727.

Guix S, Caballero S, Villena C, Bartolomé R, Latorre C, Rabella N, Simó M, Bosch A, Pintó RM 2002. Molecular epidemiology of astrovirus infection in Barcelona, Spain. J Clin Microbiol 40: 133-139.

ICTVdB Management 2006. 00.005. Astroviridae. In C BüchenOsmond, ICTVdB - The Universal Virus Database, version 3. Columbia University, New York, US.

Jiang X, Espul C, Zhong WM, Cuello H, Matson DO 1999. Characterization of a novel human calicivirus that may be a naturally occurring recombinant. Arch Virol 144: 2377-2387.

Komoriya T, Kohno H, Kimura A, Ushijima H 2003. The development of sensitive latex agglutination tests for detecting astroviruses (serotypes 1 and 3 ) from clinical stool speci- 
men. Rinsho Biseibutsu Jinsoku Shindan Kenkyukay Shi 13: 103-114.

López L, Castillo FJ, Fernández MA, Clavel A, Rubio MC, GómezLus R, Cutillas B 2000. Astrovirus infection among children with gastroenteritis in the city of Zaragoza, Spain. Eur J Clin Microbiol Infect Dis 19: 545-547.

Matsui SM, Greenberg HB 2001. Astroviruses. In BN Fields, DM Knipe, PM Holey, RM Chanock, TP Monath, JL Melnick, Roizman B, SE Straus (eds), Fields Virology, 4th ed., Lippincott-Williams and Wilkins, Philadelphia, p. 875-893.

Méndez-Toss M, Griffin DD, Calva J, Contreras JF, Puerto FI, Mota F, Guiscafré H, Cedillo R, Muñoz O, Herrera I, López S, Arias CF 2004. Prevalence and genetic diversity of human astroviruses in Mexican children with symptomatic and asymptomatic infections. J Clin Microbiol 42: 151-157.

Miranda VQS 2004. Detecção e Caracterização Molecular de Astrovírus em Crianças Menores de Dois Anos com Gastroenterite Aguda no Município do Rio de Janeiro, $R J$, MSc Thesis, Fundação Oswaldo Cruz, Rio de Janeiro, $111 \mathrm{pp}$.

Mitchell DK, Matson DO, Jiang X, Berke T, Monroe SS, Carter MJ, Willcocks MM, Pickering LK 1999. Molecular epidemiology of childhood astrovirus infection in child care centers. J Infect Dis 180: 514-517.

Naficy AB, Rao MR, Holmes JL, Abu-Elyazeed R, Savarino SJ, Wierzba TF, Frenck RW, Monroe SS, Glass RI, Clemens JD 2000. Astrovirus diarrhea in Egyptian children. J Infect Dis 182: 685-690.

Noel JS, Lee TW, Kurtz JB, Glass RI, Monroe SS 1995. Typing of human astroviruses from clinical isolates by enzyme immunoassay and nucleotide sequencing. J Clin Microbiol 33: 797-801.

Pennap G, Pager CT, Peenze I, De Beer MC, Kwaga JKP, Ogalla WN, Umoh JU, Steele AD 2002. Epidemiology of astrovirus infection in Zaria, Nigeria. J Trop Pediatr 48: 98-101.

Pereira HG, Azeredo RS, Leite JPG, Candeias JAN, Rácz ML, Linhares AC, Gabbay YB, Trabulsi JR 1983. Electrophoretic study of the genome of human rotaviruses from Rio de Janeiro, São Paulo and Pará, Brazil. J Hyg (Lond) 90: 117-125.
Pereira HG, Azeredo RS, Leite JPG, Andrade ZP, De Castro L 1985. A combined enzyme immunoassay for rotavirus and adenovirus (EIARA). J Virol Methods 10: 21-28.

Phan TG, Okame M, Nguyen TA, Maneekarn N, Nishio O, Okitsu S, Ushijima H 2004. Human astrovirus, norovirus (GI, GII), and sapovirus infections in Pakistani children with diarrhea. J Med Virol 73: 256-261.

Riechmann ER, De Cal IW, Pascual MLC, Rey CC, García MLG, Sánchez-Fauquier A 2004. Gastroenteritis aguda nosocomial y infección asintomática por rotavirus y astrovirus en niños hospitalizados. An Pediatr (Barc) 60: 337-343.

Román E, Wilhelmi I, Colomina J, Villar J, Cilleruelo ML, Nebreda V, Del Alamo M, Sánchez-Fauchier A 2003. Acute viral gastroenteritis: proportion and clinical relevance of multiple infections in Spanish children. J Med Microbiol 52: 435-440.

Schnagl RD, Belfrage K, Farrington R, Hutchinson K, Lewis V, Erlich J, Morey F 2002. Incidence of human astrovirus in Central Australia (1995 to 1998) and comparison of deduced serotypes detected from 1981 to 1998. J Clin Microbiol 40: 4114-4120.

Silva AMV, Leite EG, Assis RMS, Majerowicz S, Leite JPG 2001. An outbreak of gastroenteritis associated with astrovirus serotype 1 in a day care center, in Rio de Janeiro, Brazil. Mem Inst Oswaldo Cruz 96: 1069-1073.

Stewien KE, Durigon EL, Tanaka H, Gilio AE 1991. Ocorrência de astrovírus humanos na cidade de São Paulo, Brasil. Rev Saúde Pública 25: 157-158.

Tai JH, Ewert MS, Belliot G, Glass RI, Monroe SS 2003. Development of a rapid method using nucleic acid sequence-based amplification for the detection of astrovirus. J Virol Methods 110: 119-127.

Tanaka H, Kisielius JJ, Ueda M, Glass RI, Joazeiro PP 1994. Intrafamilial outbreak of astrovirus gastroenteritis in São Paulo, Brazil. J Diarrhoeal Dis Res 12: 219-221.

Vinjé J, Altena SA, Koopmans MP 1997. The incidence and genetic variability of small round-structured viruses in outbreaks of gastroenteritis in The Netherlands. J Infect Dis 176: 1374-1378.

Wilhelmi I, Roman E, Sánchez-Fauquier A 2003. Viruses causing gastroenteritis. Clin Microbiol Infect 9: 247-262. 
